\title{
Research of Enterprise Accounting Information System Internal Control Based on ERP
}

\author{
Huiyin Zheng \\ College of Yongzhou Vocational Technical College, Hunan, Yongzhou, 425000, China
}

Keywords: ERT, AIS, Internal control, Strategy

\begin{abstract}
With the continuous development of social economy, all industries of China have been developing rapidly. How to fully play the internal control role of enterprise AIS (accounting information system) in ERP environment, improve the accuracy of business decision-making, enhance the economic efficiency of enterprises, it has become the focus of the current problems faced by enterprises. This paper analyzes the role of ERP system for the AIS internal control, and discusses several strategies to optimize enterprise accounting information system.
\end{abstract}

\section{Introduction}

With the social and economic prosperity, advanced science and technology advances, business competition in the market pressure is also growing. ERP as an advanced information management system has been applied to many enterprises actual production management. ERP system is built on information technology, based on a systematic management thinking, through the enterprise logistics, flow, capital flow, information flow to unify overall balance and optimize the management, and coordinating the various administrative departments, focus on market-oriented business activities, thereby enhancing the core competitiveness of enterprises, in order to obtain the best economic management system in which embody the world's most advanced enterprise management theory, but also for enterprise information provides an important basis for decision-making. Therefore, in the ERP environment, take full advantage of the internal control point enterprise accounting information, give full play to the functions of ERP system, for the development of enterprises, it has an important role.

\section{Features of enterprise accounting information system internal control under ERP environment}

\section{Accounting service model is optimized}

Accounting Information System in ERP environment is mainly built on the basis of a computer to manage accounting as the core information system. In addition to the process-based accounting business, but also the production and operation activities which are related to the human, material, financial and other information together to manage customer needs and will also enterprises combine production and business activities, and to carry out the production plan, cash flow, cost control and other aspects, effectively reduce the corporate resources, waste of funds, and effectively improve the economic efficiency of enterprises [1]. However, this approach of ERP automation, information technology and diversification, but also to a certain extent, increased the risk of accounting information system operation. Therefore, the need for enterprise accounting information system ERP environment to regulate and effective restraint, so that the real ERP system to play its role in the accounting information system.

\section{ERP information system has realized human-machine exchange work}

ERP systems automate business model, effectively reducing the workload of the accounting staff, but this automatic mode, cannot completely replace the work of the accounting staff, accounting staff still need to manually enter the relevant information and data. In practice, ERP information 
management systems and accounting personnel manage and control the accounting information, accounting information management to improve efficiency.

\section{Attach importance to data}

Accounting information management system ERP environment, through computer processing of the data entry mode, this approach greatly reduces manual errors and improves the accuracy of the data information. At the same time, this approach also requires enterprises to continuously improve the security of data processing.

\section{Role of ERP in enterprise accounting information system internal control}

ERP as an advanced internal control tool, plays an important role in the enterprise internal management. However, it should be noted that, ERP is just a tool of internal control as internal control systems; it cannot completely replace the entire system for enterprise management. As the ERP with a high degree of information-intensive, fast transfer, handling a wide range of other advantages, the ability to corporate finance, production, marketing and other aspects of information for effective control, and then provide the necessary basis for corporate decision-making, ERP information management system in the enterprise the internal control plays an important role, mainly in the following aspects:

\section{ERP system can provide important support for enterprise internal control}

ERP system itself is an internal control system, the ERP systems into internal control and management of enterprises which, ERP systems can provide important support for the internal control of the enterprise. First, ERP systems can effectively solve the problem related information between external and internal corporate departments involved. China's traditional accounting information system, just collect information related to the department, and the flow of information between other sectors, relatively speaking, it is more closed ${ }^{[2]}$. ERP system accounting information can be collected, but also on the production, logistics management, financial management and human resources management among the information collected, through comprehensive control, can provide an important basis for business decisions. Second, ERP accounting information system but also is one of production activities of enterprises effective control. ERP management system by setting the parameters for the entire production and business activities of enterprises to implement automation and control, by automatically recording customer information, inventory quantities, the financial statements and other processes of information, to strengthen effective monitoring of corporate resources, help to improve the whole enterprise internal control management level.

\section{It helps to enhance the implementation of enterprise internal control}

Enterprise accounting information system, not only can enhance the accounting information control, but also to strengthen the enterprise sector's production and operational control, help enterprises to strengthen control of the entire industry. At the same time, ERP system through the appropriate detection and prevention, effectively reducing the business risk running them through the relevant financial information promptly corrected and maintain and improve the supervision of information data to enhance the security of corporate financial information, for the enterprise the entire production and business activities, have an important role in safeguarding.

\section{It reinforces enterprise internal supervision}

The enterprise accounting information system internal control under ERP environment mainly uses human-computer exchange model is mediated by computer, by artificial accounting information system of internal control internal input mode, indicators, procedures and other information command, the enterprise accounting information systems to monitor real and effective, and thus play a monitoring function of accounting information systems. However, in order to truly ensure the effectiveness of enterprise ERP environment accounting information system, should continue to 
strengthen monitoring efforts, according to the business situation, timely adjustment of relevant control program and execute the command.

\section{Strategies to optimize enterprise AIS internal control under ERP environment}

The enterprise accounting information system internal control under ERP environment still exists many problems in practical work, such as imperfect internal control environment, information disclosure of accounting records, computerized accounting audit lag, in the context of economic globalization under optimize the ERP accounting information systems, should be from the following aspects:

\section{Reinforce internal control awareness of enterprise AIS under ERP environment}

In ERP environment, the company's internal control and information processing methods are changed greatly, however, the internal control to achieve the desired goal has not changed, still desirable to optimize the internal control management, improve management decision-making level of enterprises, and improving the competitiveness ${ }^{[3]}$. Therefore, the enterprise accounting information system ERP environment, should still be to strengthen internal controls as a business management focus, to improve the economic efficiency of enterprises as the goal, to strengthen the awareness of internal control. For businesses, we should focus on strengthening its cost concept to employees, strengthen the quality of construction employees, and constantly enhance their literacy practitioners to ERP as the core, the establishment of internal control mechanisms and enterprise development to adapt to continuously improve the internal management of enterprises Level. Meanwhile, the sector enterprises and employees of various departments, but also to establish internal control awareness ERP environment, strengthen cooperation between the team and enhance the effectiveness of each department flow of information, and improve the implementation of the effect of ERP information management system, improve corporate decision-making accuracy, optimize economic efficiency of enterprises.

\section{Complete enterprise internal control environment}

Good internal control environment is important to ensure that enterprises implement a comprehensive internal control. The ERP enterprise information into the accounting internal control among the traditional accounting information system will impact to some extent, the implementation of internal accounting controls also exist to some extent. Therefore, changing the accounting information in the course of business processes, companies should target their own integrated discovery, facilitating the flow of information in various sectors, while focusing on relevant information is carefully selected to ensure that financial information is entered, try true, accurate, improve the effectiveness of corporate accounting information. At the same time, enterprise information management systems into the ERP enterprise internal control and management which should focus on ERP system upgrade and update and improve the ability to expand ERP information systems, try to extend the life cycle of ERP information systems. Viruses appear in the ERP system or when due to some operational errors caused by software failure, to focus on relevant information timely backup, make sure valuable information is not lost, protect the integrity of the entire information resources. To focus on strengthening of the extreme and the virus prevention, the establishment of appropriate security measures, and have to enhance network security monitoring, including data encryption, firewall technology, performing user authentication, when to pay attention to the password encryption, set access privileges like. Strengthen the supervision network environment, create a good environment for enterprise internal control, companies can also establish related online notary public, focusing on corporate financial information protected from disclosure of relevant information has been tampered with or caused by the financial crisis ${ }^{[4]}$. Finally, enterprises should pay attention to the relevant division finance officer responsibilities and obligations, as far as possible responsibilities to individuals, companies can also implement job rotation system, strengthen supervision and control departments, raise awareness of financial risks financial staff for 
enterprises internal control to create a good environment, promote the upgrading of the internal control management level.

\section{Reinforce file management of AIS}

File management accounting information systems, accounting information system among the priorities. First, companies should pay attention to the management arrangements for the Commissioner in charge of the file, while a clear job responsibilities of personnel records management, focusing on the responsibilities to individuals. For example, to specify file managers are not free to change the system program. Furthermore, we should focus on improving the examination and approval system archives, archives of borrowing strictly regulate the process, to avoid disclosure of relevant information to ensure the security of accounting information. Finally, focusing on the accounting records were duplicated backup, and stored in different places, and prevent damage caused by the storage device file information is lost. In order to ensure the reliability and security of files, paper files can be implemented and electronic records dual format, while focusing on the use of new technology and equipment for the protection of archives.

\section{Improve AIS administrators' quality}

Strengthening literacy accounting information systems managers, accounting information systems to improve internal control in ERP environment has important significance. Only accounting staff only improve their literacy, in order to strengthen the real implementation of the internal control fundamentally. First, the accounting information system managers to understand and master the operating mechanism accounting business functions in order to better control and supervision of the accounting business processes; second, accounting information system managers to focus on strengthening its own network knowledge and learning, focusing on accounting knowledge and learning, focusing on learning the accounting information system maintenance knowledge to the accounting information system fails, it can timely maintenance, improve the security of the accounting system. Finally, the accounting information system managers, but also pay attention to establish a sense of responsibility, focusing on the processing of accounting information system supervision, reduce the accounting information system due to the risk of human error.

\section{Enhance internal audit and reduce internal control risk}

Internal audit is an important part of enterprise internal control, whose main objective is to strengthen the supervision of internal accounting. Internal audit generally include the following: audit of accounting information, check the information is correct, as well as compliance with internal control relevant signature requirements; examine whether there is electronic data and written data consistency; supervise the way data is stored is in compliance with legal norms. In the ERP environment, human-machine interaction control management, accounting information system is the basic way to handle the business; therefore, in order to further control the internal control risk, they should improve the internal audit system ${ }^{[5]}$. Internal auditors should be familiar with ERP Environment Accounting Information Systems running processes. Work in practice, internal auditors should also pay attention to their own accounting checks, when it finds problems, we should pay attention to its own accounting experience, starting from the actual situation, to find the right solution to ensure that the accounting information system work safety and effectiveness, thus improving the efficiency of accounting

\section{Conclusions}

Under ERP environment, companies should continue to strengthen internal control of accounting information systems, specifically the important role of ERP systems for internal control, while focusing on strengthening internal environment, improve the level of corporate accounting information records management, strengthen the internal audit and improve literacy accounting information system managers, accounting information systems to improve operational safety, give 
full play to the role of ERP systems for enterprise accounting information system, and constantly improve the level of corporate internal management accounting information, enhance the economic efficiency of enterprises, improve the competitiveness of enterprises, so that enterprises in the fierce competition in the market.

\section{References}

[1] Shi Chunguang. Analysis on financial AIS internal control optimization strategy in ERP. Journal of Contemporary Accounting,2014,(8):49-50.

[2] Li Jingsi. Research on enterprise AIS internal control design in ERP environment. Business Accounting,2012,(24):34-36.

[3] Chen Yan. Discussion on SME AIS in ERP. Value Egineering,2014,(8):191-192.

[4] Wang Chunmei, Wang Tieyuan, He Pingji et al. Research on internal control of purchasing module in ERP environment. China Management Information,2011,(5):2-3.

[5] Liu Yanjie. Accounting internal control in ERP environment. Business Economy, 2011, (23) : 103-104. 